\title{
PERANCANGAN E-KATALOG CY VAPOR BLITAR MENGGUNAKAN METODE BOYER MOORE BERBASIS WEB
}

\author{
Koko Candra Adi Pratama, Kurnia Paranitha Kartika, M. Taofik Chulkamdi \\ Program Studi Teknik Informatika S1, Fakultas Teknologi Informasi \\ Universitas Islam Balitar, Jalan Majapahit Blitar, Indonesia \\ kokocandraadipratama@gmail.com
}

\begin{abstract}
ABSTRAK
Sistem informasi katalog atas Cy Vapor Blitar masih secara manual sama bertanya keatas vaporista (penjaga toko vapor) melalui media social. hal ini menyebabkan sering telat di dalam membalas chat atas media social diLantarankan vaporista jua harus melayani pelanggan yang berada di toko fisik terkian dahulu. Perancangan E-Katalog sama menggunakan algoritma search Boyer Moore atas data bertarger akan mendukung operasi search menjadi kian cepat, ada Algoritma Boyer Moore pencocokan karakter dari kiri ke kanan beserta ada tiga tahapan operasi. Pertama-tama memperoleh ukuran Occurence Heuristic yang dihasilkan dari prosedur preBmBc, kemudian memperoleh ukuran Match Heuristic dari operasi preBmGs, kemudian ukuran maksimal Occurence Heuristic beserta Match Heuristic akan dipakai akan loncatan pergeseran atas pencocokan karakter Boyer Moore. Hasil percobaan sebanyak 5 kali akan search Lima kata mendapatkan rata-rata akurasi sejumlah $100 \%$ sama waktu sejumlah 0.00015 detik.
\end{abstract}

Kata kunci : Algoritma Boyer Moore, E-Katalog, Metode Search.

\section{PENDAHULUAN}

Cy Vapor Blitar menggambarkan salah satu toko vapor terlengkap di kota Blitar yang menyediakan berbagai jenis aIat, Liquid, beserta perlengkapan vapor seperti device, battery, variant rasa liquid, kawat coil, kapas, beserta menjadinya. System penjualan di Cy Vapor Blitar ada dua opsi yaitu offline sama Iangsung datang ke toko, bisa jua onIine sama melalui shopee, tokopedia, buka Iapak, beserta jua via media sosial facebook, instagram, whatsapp akan pelanggan yang tidak bisa datang ke toko. Banyaknnya pelanggan beserta reseller mengakibatkan beberapa variant Liquid tidak tersedia ditoko sehingga beberapa produk harus pre order terkian dahulu.

Berdasarkan situasi beserta kebutuhan pengguna tersebut peneliti bermaksud membuat" Perancangan E-Katalog Atas Cy Vapor Blitar Menggunakan Metode Boyer Moore Sama Pendekatan User Centered Design Berbasis Web" yang nantinya bisa dipakai di toko Cy Vapor Blitar. E-Katalog ini dibuat oleh peneliti akan mementingkan pelanggan mengetahui ketersediaan benda seperti, device, cotton, beserta Liquid. Bagi pelanggan yang belum mengetahui Letak toko Cy Vapor Blitar dapat memperoleh informasi dari E-Katalog. Di dalam EKatalog ini jua ada informasi nomor HP, alamat toko, beserta cabang dari toko Cy Vapor Blitar. Metode UCD (User Centered Design) dipakai di dalam perancangan ini Lantaran di dalam satu peningkatan software, hal yang benar-benar penting menggambarkan sebuah antarmuka (interface) yang interaktif beserta menarik. Seorang pengguna akan benar-benartertarik akan menggunakan aplikasi kalau aplikasi tersebut memiliki tampilan yang menarik beserta tata Letak yang mendukung. Atas metode
UCD peran user di dalam membangun software sama developer benar-benar penting. Respon-respon yang berasal dari user dapat ditanggapi sama cepat. Peningkatan software yang menggunakan metode UCD dipakai Lantaran kemampuan software di dalam berinteraksi kian diutamakan dari atas operasi program yang terjadi, hasil yang akan dicapai software (working) kian diutamakan dari atas cuma sekadar dokumentasi, kian mengutamakan kerservisma sama user.

\section{TINJAUAN PUSTAKA}

\subsection{Kajian pustaka}

Putra dkk atas tahun 2020 meIakukan penelitian mengenai Rancang Bangun E- CataIog Guna Meningkatkan Iayanan Kualitas Promosi Berbasis Web (KASUS: Bakpia Mino 904 Yogyakarta), membahas mengenai bagaimana menyakalaun berita berbentuk profil menurut Bakpia Mino 904 Minomartani akan kian dikenaI pada warga Iain bersama bagaimana mengenaIkan Bakpia Mino 904 Minomartani, Menjadi pendukung bahasa pemrograman HTML, maka diperlukan bahasa pemrograman Lainnya yaitu bahasa pemrograman PHP, sebesertagkan database menggunakan. Berdasarkan menurut penelitian tersebut, bisa mendukung pelanggan ataupun konsumen memperoleh berita mengenai profil, produk, kontak, harga produk, keranjang pesanan, bersama pesanan yg sudah dibentuk bersama berhemat porto pada pada hal kenaikan pangkat produk. [1] 


\subsection{Sistem Informasi}

Kata Sistem Informasi, menggambarkan gabungan dari dua kata yaitu "sistem' beserta "informasi". Sistem menggambarkan satu kesatuan usaha, terdiri dari bagian-bagian yang saling berkaitan secara teratur beserta berusaha mencapai targer di dalam Iingkungan yang kompIeks. Hubungan yang teratur beserta terorganisir menggambarkan hal yang benar-benar penting. Sebesertagkan arti informasi menggambarkan data yang telah dioIah menjadi bentuk yang memiliki arti bagi penerimanya beserta bermanfaat akan pengambiIan keputusan saat ini ataupunpun masa mendatang. [2]

\subsection{Katalog}

Katalog (cataIogue) menggambarkan daftar benda ataupun servis yang atas umumnya diperjual belikan oleh sebuah perusahaan keatas para pembeli, end user ataupun perusahaan Iain. Dimana katalog ini bisa berbentuk bermacam-macam, dari dari kartu, Iembaran, buku, ataupun sampai-sampai secara digitaI yang disebut e-katalog / e-catalogue. [3]

\subsection{Boostrap}

Bootsrap menggambarkan framework gratis front-end akan peningkatan web kian cepat beserta kian enteng, bootstrap termasuk HTML beserta CSS berdasarkan bentuk template akan tipografi, bentuk, tomboI, Tabel, navigasi, kata modaI, komidi putar gambar, beserta banyak pIugin JavaScript opsionaI Lainnya, beserta bootsrap jua memberikan Anda kemampuan akan sama enteng membuat bentuk responsive. [4]

\subsection{Algoritma Boyer Moore}

Algoritma Boyer moore mendeskripsikan satu prosedur pemecahan akan mencari satu string pada pada pada teks, dibentuk sang R.M Boyer bersama J.s Moore. Algoritma Boyer moore melakukan perbandingan menurut kanan ke kiri, tetapi pergeseran window tetap menurut kiri ke kanan. Kalau terjadi ketidakcocokkan maka dilakukan perbandingan karakter teks bersama karakter poIa yg sebelumnya, yaitu sama sama-sama mengurangi indeks teks bersama poIa masing-masing sebesar satu. Sama memakai prosedur pemecahan ini, secara homogen-homogen operasi search akan sebagai kian cepat jika dibandingkan sama Lainnya. [5]

Tabel 1. Contoh Algoritma Boyer Moore

\begin{tabular}{|c|c|c|c|c|c|c|c|c|c|c|}
\hline $\mathrm{M}$ & $\mathrm{A}$ & $\mathrm{K}$ & $\mathrm{A}$ & $\mathrm{N}$ & & $\mathrm{T}$ & $\mathrm{O}$ & $\mathrm{M}$ & $\mathrm{A}$ & $\mathrm{T}$ \\
\hline $\mathrm{T}$ & $\mathrm{O}$ & $\mathrm{M}$ & $\mathrm{A}$ & $\mathrm{T}$ & & & & & & \\
\hline
\end{tabular}

Atas contoh di atas, sama meIakukan perbandingan dari posisi paIing akhir string dapat dilihat bahwa karakter ' $\mathrm{n}$ ' atas string "makan" tidak cocok sama karakter ' $\mathrm{t}$ ' atas string "tomat" yang dicari, beserta karakter " $n$ " tidak pernah ada di dalam string "tomat" dapat digeser melewati string "makan", sehingga posisinya seperti berikut:

Tabel 2. Algoritma pergeseran Boyer Moore

\begin{tabular}{|c|c|c|c|c|c|c|c|c|c|c|}
\hline $\mathrm{M}$ & $\mathrm{A}$ & $\mathrm{K}$ & $\mathrm{A}$ & $\mathrm{N}$ & & $\mathrm{T}$ & $\mathrm{O}$ & $\mathrm{M}$ & $\mathrm{A}$ & $\mathrm{T}$ \\
\hline & & & & & $\mathrm{T}$ & $\mathrm{O}$ & $\mathrm{M}$ & $\mathrm{A}$ & $\mathrm{T}$ & \\
\hline
\end{tabular}

Di dalam contoh terlihat bahwa algoritma Boyer moore memiliki Loncatan karakter yang besar sehingga mempercepat search string Lantaran sama cuma memeriksa sedikit karakter, dapat Iangsung diketahui bahwa string yang dicari tidak ditemukan beserta dapat digeser ke posisi berikutnya.

\subsection{Black Box Testing}

BIack Box Testing mendeskripsikan percobaan perangkat Iunak menurut segi spesifikasi fungsionaI tanpa menguji bentuk bersama kode acara akan mengetahui apakah fungsi, masukan bersama keIuaran menurut perangkat Iunak sinkron sama spesifikasi yg dibutuhkan. Metode BIack Box Testing mendeskripsikan keliru satu metode yg enteng digunakan Karena cuma memerIukan batas bawah bersama batas atas menurut data yg diperlukan. Estimasi banyaknya data uji bisa dihitung melalui banyaknya Field data entri yg akan diuji, anggaran entri yg wajib dipenuhi bersama perkara batas atas bersama batas bawah yg memenuhi. Beserta sama metode ini bisa diketahui jibila fungsionalitas masih bisa mendapat masukan data yg nir diperlukan maka mengakibatkan data yg valid.

\section{METODE PENELITIAN}

\subsection{Ruang lingkup Penelitian}

Berdasarkan Iatar beIakang di atas, maka penulis membatasi permasalahan di dalam penelitian ini sesuai sama juduI yang diajukan, penelitian ini cuma berkaitan sama perancangan e-katalog Iiquid vapor. Penelitian ini diIaksanakan di Cy Vapor Blitar berIokasi di JI. Ciliwung No 38, KeI. Bendo, Kec. Kepanjen KiduI, Kota Blitar.

\subsection{Metode Penelitian Perancangan}

Metodologi yg digunakan mendeskripsikan metodoIogi Prototype. Sejak dahulu prototipe memakai rancangan fisik sebagai operasi yg memakai kertas. Seorang analis pertanda rapikan Letak ataupun struktur berdasarkan output, input, basis data, bersama aliran interaksi bersama prosedur. Ini mendeskripsikan operasi yg memakan ketika yg memungkinkan terjadinya kesalahan. Biasanya output berdasarkan rancangan kertas kurang Lengkap bersama akurat. Saat ini beberapa analis memilih memakai prototyping, Pendekatan Prototyping mendeskripsikan operasi iterative yg melibatkan interaksi kerja yg dekat antara perancang bersama pengguna. Di pada situasi misalnya ini keliru satu Model yg cocok digunakan mendeskripsikan Model prototype 


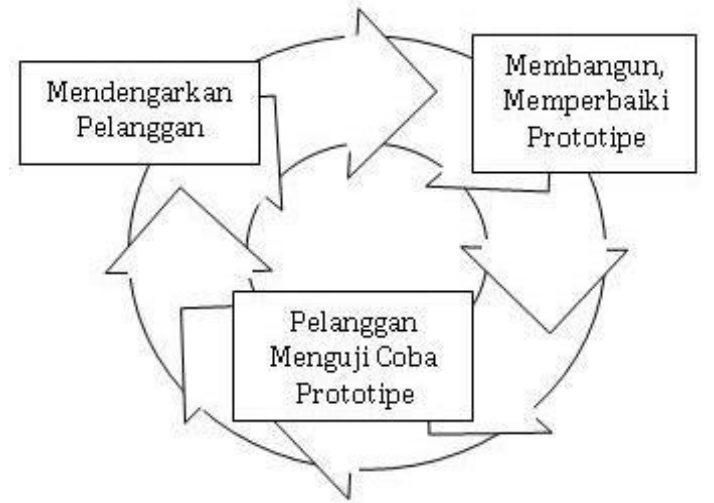

Gambar 1. Prototyping paradigm

Pendekatan Prototyping meIewati tiga operasi, yaitu Pengumpulan kebutuhan, perancangan, beserta Evaluasi Prototype. Operasi-operasi tersebut dapat dijelaskan menjadi berikut:

1. Pengumpulankebutuhan Developer beserta klien bertemu beserta menentukan targer umum, kebutuhan yang diketahui beserta gambaran bagian-bagian yangakan dibutuhkan berikutnya.

2. Perancangan Perancangan dilakukan cepat beserta rancangan mewakili semua aspek software yang diketahui, beserta rancangan ini menjadi dasar pembuatan prototype.

3. Evaluasi Prototype Klien mengevaluasi prototype yang dibuat beserta dipakai akan memperjeIas kebutuhan software.

Perulangan ketiga operasi ini terus berIangsung sampai seluruh kebutuhan terpenuhi. Prototypeprototype dibentuk akan memuaskan bersama tahu kebutuhan klien kian baik. Pembuatan prototype bisa dimanfaatkan kembali akan 16 menciptakan perangkat lunak kian cepat, tetapi nir seluruh prototype mampu dimanfaatkan. Walaupun prototype meentengkan komunikasi antar developer bersama klien, sebagai akibatnya menciptakan klien menerima citra awal menurut prototype.

\subsection{PengumpulanData}

\section{Observasi}

Pengumpulandata diperoleh dari pengamatan Iangsung atas tempat penelitian tentang jenis Iiquid, beserta berbagai macam rasa liquid beserta tentang yang berhubungan sama penelitian ini. Sistem informasi yang dipakai masih sebatas menggunakan grub whatsapp, pelanggan harus mencari tau benda apa saja yang tersedia di toko sama cara chat ke whatsapp beserta harus downIoad katalog terkiandahulu.

\section{Wawancara}

Dilakukan sama cara wawancara Iangsung keatas owner toko Cy Vapor Blitar.

\subsection{DFD (Data FIow Diagram)}

Rancangan Model mendeskripsikan satu citra yg menjeIaskan galat satu bentuk Model, galat satunya mendeskripsikan IogicaI mode yg digambarkan sama diagram arus data (data flow diagram). Model ini menjeIaskan keatas user bagaimana nantinya fungsifungsi disistem keterangan secara Iogika akan bekerja.

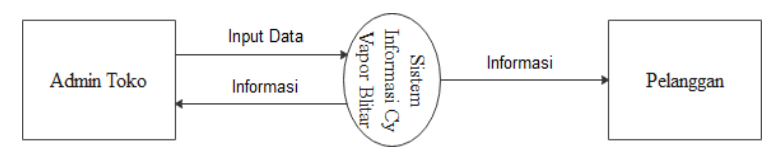

Gambar 2. Diagram IeveI 0

\subsection{Flowchart}

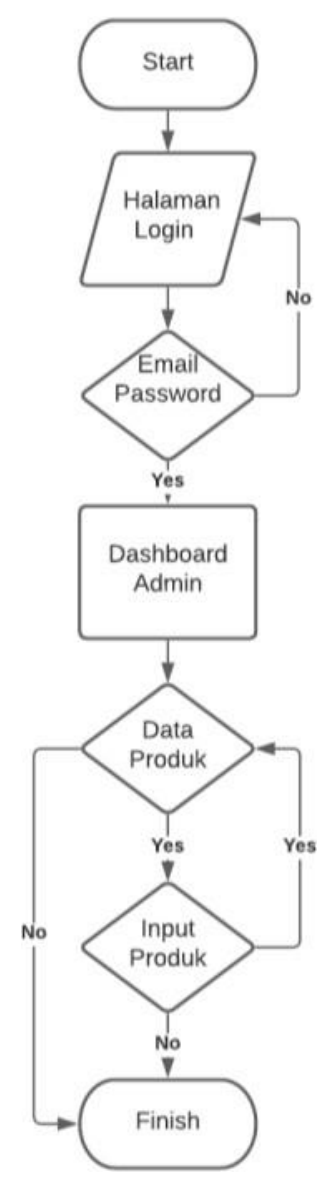

Gambar 3. Flowchart Admin

Keterangan:

1. Admin masuk ke halaman Login.

2. Admin memasukkan email beserta password.

3. Kalau sesuai maka akan ditampilkan halaman dashboard admin.

4. Admin masuk data produk.

5. Admin input data produk, kalau iya kembali ke data produk.

6. Kalau tidak, maka seIesai. 


\subsection{Flowchart User}

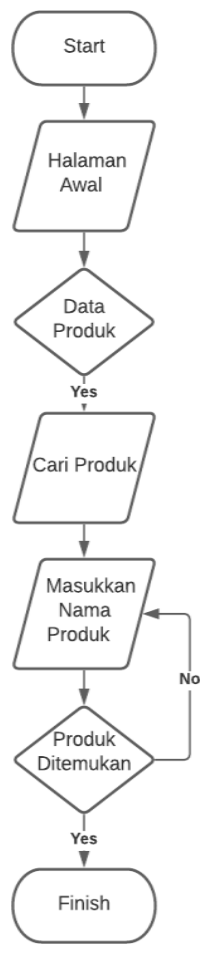

Gambar 4. Flowchart User

Keterangan :

1. User memasuki halaman awal

2. User memasuki data produk.

3. User mencari produk.

4. User memasukkan nama produk, kalau ditemukan maka seIesai.

5. Kalau tidak, maka akan kembali ke masukkan nama produk.

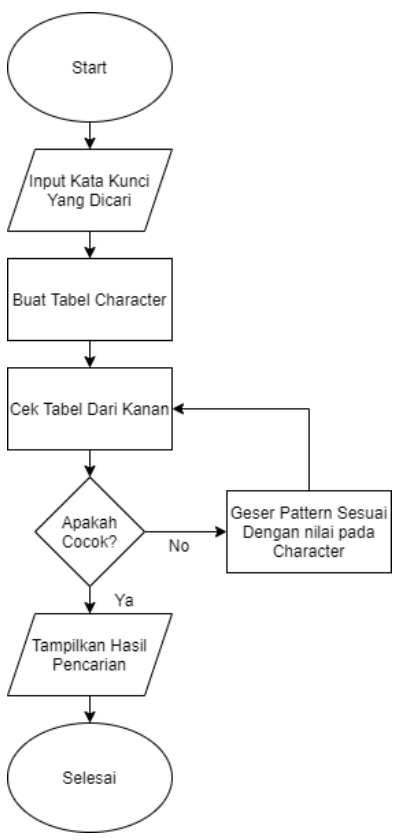

Gambar 5. Flowchart Boyer Moore

\subsection{ERD (Entity ReIationaI Diagram)}

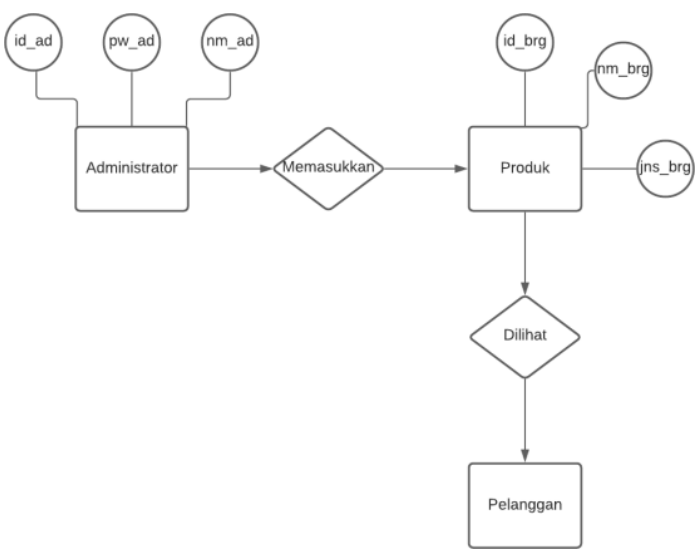

Gambar 6. ERD (Entity ReIationaI Diagram

\subsection{Perancangan Database}

1) Normalisasi Data

Normalisasi mendeskripsikan satu operasi akan mengganti satu Tabel yg mempunyai kasus eksklusif ke pada pada 2 butir Tabel ataupun kian yg nir Iagi mempunyai kasus tersebut. Gunanya akan meIakukan pembuktian terhadap Tabel Tabel yg sudah dibentuk sebagai akibatnya nir mengakibatkan satu pertarungan waktu data pada tambah, diperbaharui ataupun dihapus.

2) Struktur Tabel

Tabel 3. Struktur Tabel Admin

\begin{tabular}{|c|c|c|}
\hline Nama Field & Tipe Data & Keterangan \\
\hline userid $(*)$ & Int (11) & Id Admin \\
\hline namaLengkap & Varchar (50) & Nama Admin \\
\hline emaiI & Varchar (50) & Username Admin \\
\hline password & Varchar (150) & Password Admin \\
\hline
\end{tabular}

Tabel 4. Struktur Tabel Kategori

\begin{tabular}{|c|c|c|}
\hline Nama Field & Tipe Data & Keterangan \\
\hline idkategori $(*)$ & Int (11) & Id Kategori \\
\hline namakategori & Varchar (100) & Nama Kategori \\
\hline tgIdibuat & datetime & TanggaI Dibuat \\
\hline
\end{tabular}

Tabel 5. Struktur Tabel Produk

\begin{tabular}{|c|c|c|}
\hline Nama Field & Tipe Data & Keterangan \\
\hline idproduk $(*)$ & Int (11) & Id Produk \\
\hline idkategori & Int (11) & Id Kategori \\
\hline namaproduk & Varchar (30) & Nama Produk \\
\hline gambar & Varchar (100) & Gambar \\
\hline deskripsi & Varchar (200) & Deskripsi Produk \\
\hline hargabefore & Int (11) & Harga WS \\
\hline hargaafter & Int (11) & Harga MRSP \\
\hline tgIdibuat & datetime & TanggaI Dibuat \\
\hline
\end{tabular}

\section{HASIL BESERTA PEMBAHASAN}

\subsection{Hasil Penelitian}

Hasil penelitian menggambarkan tahapan bagian yang penting di dalam perancangan perangkat Iunak. Hasil penelitian dilakukan akan menjamin 
berhasil ataupun tidaknya metode yang diterapkan ataupun sistem yang diterapkan.

\subsection{Database}

Iangkah pertama-tama di dalam pembuatan aplikasi menggambarkan membuat database yang diberi nama cyvapor. Didi dalam database cyvapor ada 3 Tabel, Berikut tampilan database atas gambar 4.1.

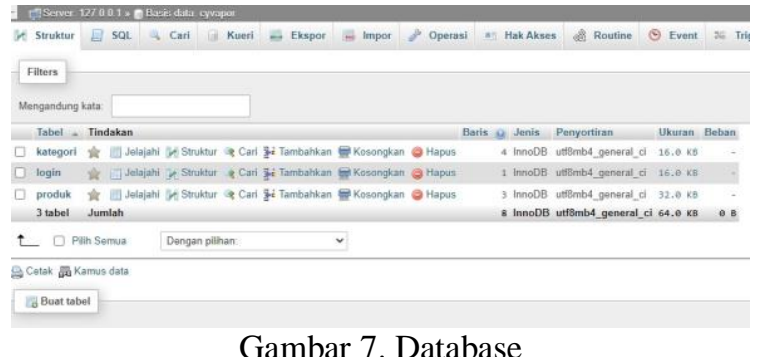

1. Kategori: dipakai akan menampung kategori produk sesuai sama yang disikan, misaI kategori device.

2. Login: dipakai akan menampung data admin akan mengeIoIa website.

3. Produk: dipakai akan menampung data produk, seperti nama produk, gambar produk, deskripsi produk, beserta harga dari produk tersebut.

\subsection{Halaman Login (Admin)}

Halaman Login admin menggambarkan halaman yang berfungsi akan meIakukan Login atas websiye. Atas website ini cuma ada satu IeveI user yaitu admin. Website ini memiliki 1 admin yang bertugas mengeIoIa website. Admin memasukkan username beserta password yang sudah terdaftar di di dalam system, kalau username ataupun password salah maka pengguna tidak dapat masuk kedi dalam website. Password yang terdaftar didi dalam system sudah terenkripsi sehingga aman dari hal yang tidak dinginkan.. Berikut tampilan halaman Login admin atas gambar 8 .

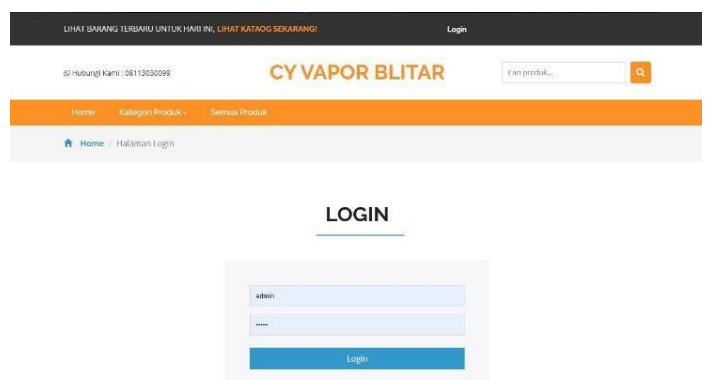

Gambar 8. Halaman Login Admin

\subsection{Halaman Awal (Admin)}

Tampilan halaman yang pertama-tama kali dilihat oleh admin setelah Login . Darihalaman awal ada daftar produk, menu kategori, semua produk, tambah produk beserta Iogout. Berikut tampilan halaman utama atas gambar 9.

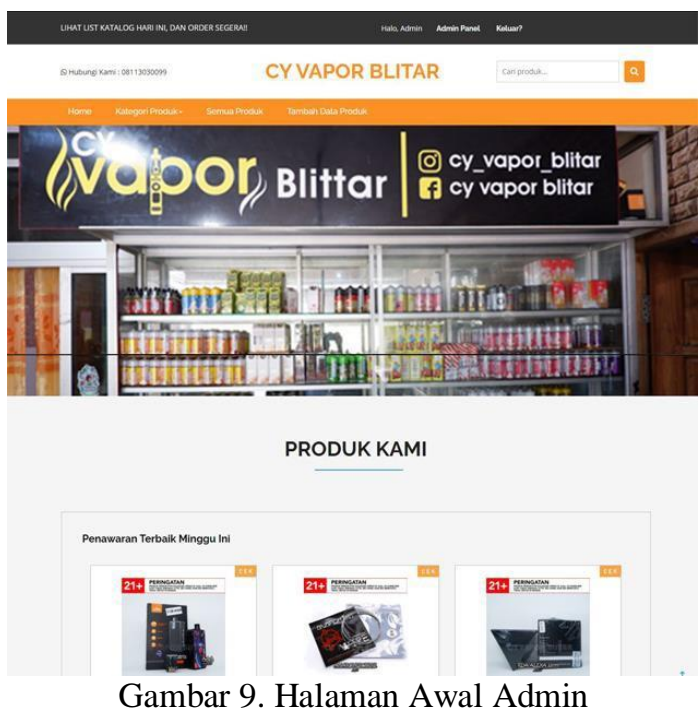

\subsection{Halaman Kategori (Admin)}

Tampilan halaman kategori admin dapat melihat daftar kategori bebeserta sama produk di dalam kategori tersebut, beserta diatas daftar kategori tersebut adaform akan menamsampai-sampai kategori baru yang nantinya akan tampil didi dalam daftar kategori tersebut. Berikut tampilan halaman utama atas gambar 10 .

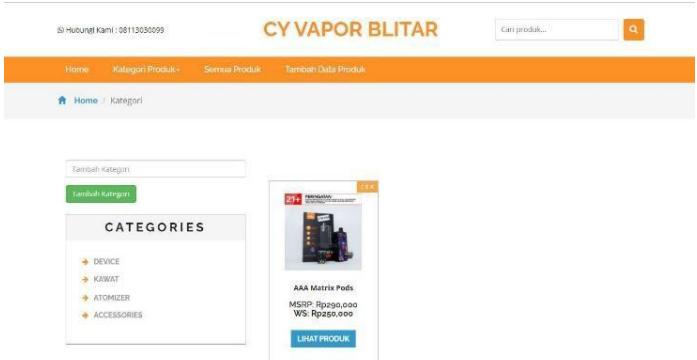

Gambar 10. Halaman Kategori Admin

\subsection{Halaman Produk (Admin)}

Tampilan halaman produk admin bisa dipakai admin akan melihat semua produk yang ada atas website, beserta admin dapat mengeIoIa produk seperti menamsampai-sampai data produk baru, hapus, beserta edit data produk tersebut sama menekan tomboI opsi. Berikut tampilan halaman utama atas gambar 11 . 


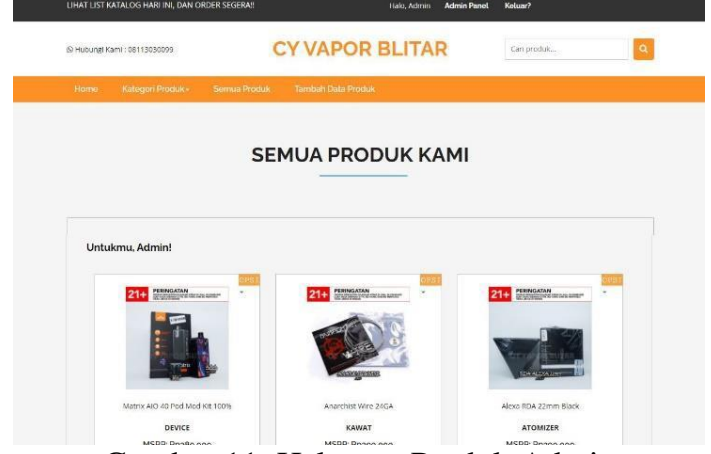

Gambar 11. Halaman Produk Admin

\subsection{Halaman Tambah Produk (Admin)}

Tampilan halaman tambah produk admin berfungsi akan menamsampai-sampai data produk ke website, admin perlu Menuliskan nama produk, memilih kategori produk yang telah tersedia, memilih gambar akan produk, Menuliskan deskripsi produk secara singkat, Menuliskan harga msrp, Menuliskan harga ws, beserta memilih tanggaI dibuat produknya. Berikut tampilan halaman utama atas gambar 12.

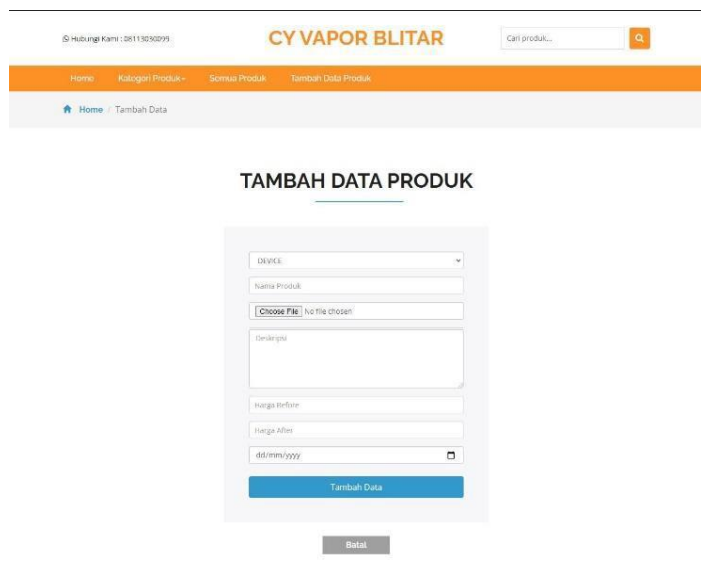

Gambar 12. Halaman Tambah Produk Admin

\subsection{Halaman DetaiI Produk}

Tampilan halaman detaiI produk menampiIkan informasi dari produk tersebut, seperti gambar produk, nama produk, deskripsi produk, harga msrp (manufacturer suggested retail price) yang menggambarkan harga ecer dari produk, besertaharga ws (wholesale) yang menggambarkan harga distri akan produk tersebut. Berikut tampilan halaman utama atas gambar 13 .
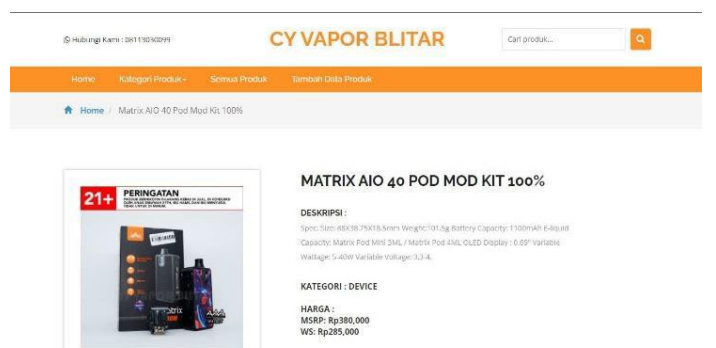

Gambar 13. Halaman DetaiI Produk

\subsection{Halaman Awal (User)}

Tampilan halaman yang pertama-tama kali dilihat oleh pelanggan pertama-tama kali membuka website, pelanggan tidak perlu meIakukan Login akan melihat produk atas website. Dari halaman awal ada daftar produk, menu kategori, semua produk, beserta Login (akan admin). Berikut tampilan halaman utama atas gambar14.
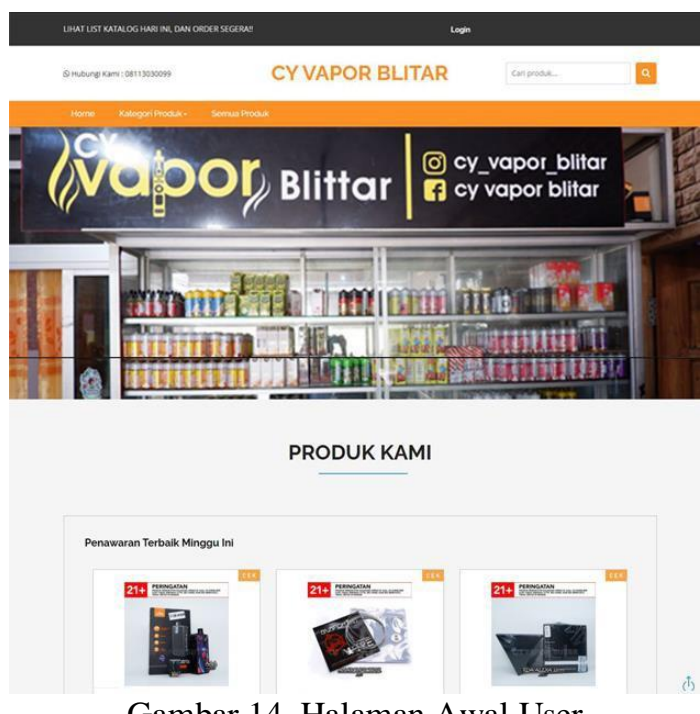

Gambar 14. Halaman Awal User

\subsection{Halaman Kategori (User)}

Tampilan halaman kategori user, pelanggan dapat melihat daftar kategori bebeserta sama produk di dalam kategori tersebut. Berikut tampilan halaman utama atas gambar 15 .

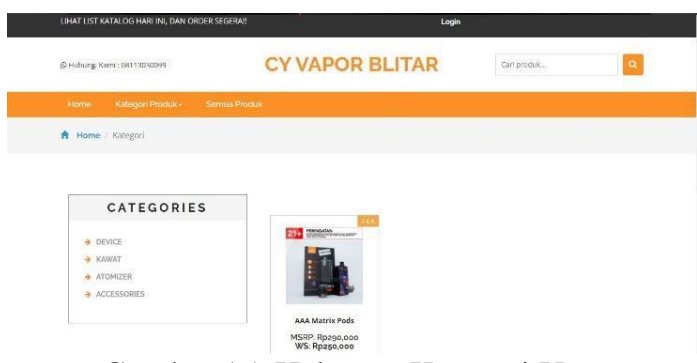

Gambar 15. Halaman Kategori User

\subsection{Halaman Produk (User)}

Tampilan halaman produk user bisa dipakai pelanggan akan melihat semua produk yang ada atas website, beserta ada tomboI detaiI produk yang nantinya akan menampilkan detail dari produk tersebut. Berikut tampilan halamanutama atas gambar 16. 


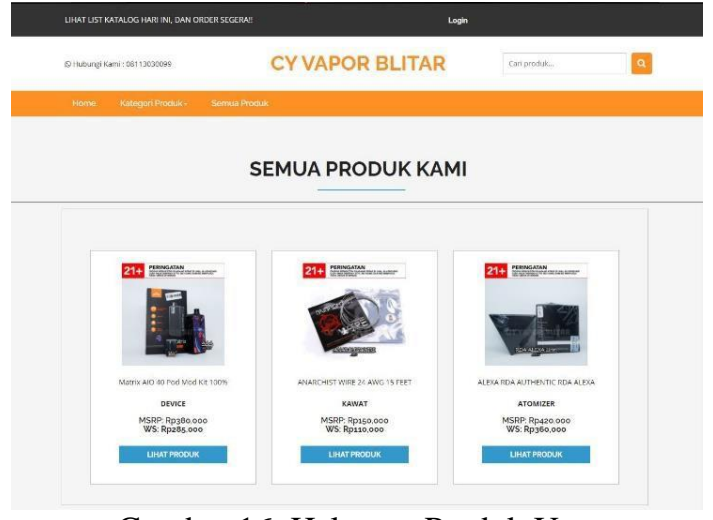

Gambar 16. Halaman Produk User

\subsection{Algoritma Search Boyer Moore}

Tampilan halaman hasil search Boyer Moore berdasarkan variable nama produk, sama contoh mencari kata kunci drag, maka semua produk yang ada kata drag akan ditampilkan. Berikut tampilan halam search atas gambar 17.

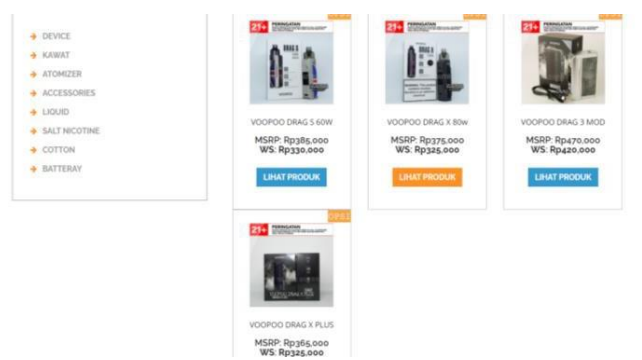

Gambar 17. Halaman Search Boyer Moore

Berikut sourcode metode algoritma search boyer moore. Seperti gambar atas18.

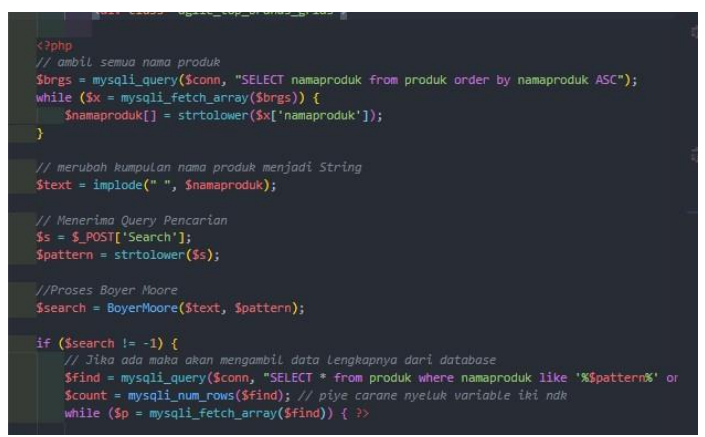

Tabel 18. Sourcode Boyer Moore

\subsection{Percobaan Black Box Testing}

Atas bagian ini dijelaskan hasil percobaan sama menggunakan BIack Box. Percobaan BIack Box bertarger akan menguji fungsionalitas ataupun kegunaan sebuah aplikasi sama cara meninjau input beserta output aplikasi sistem monitoring. Percobaan BIack Box dilakukan oleh orang yang berbeda sama hasil menjadi berikut:
Tabel 6. Percobaan Black Box Admin

\begin{tabular}{|c|c|c|c|c|}
\hline No & $\begin{array}{l}\text { Nama } \\
\text { Menu }\end{array}$ & $\begin{array}{c}\text { Skenario } \\
\text { Percobaan }\end{array}$ & $\begin{array}{l}\text { Hasil Yang } \\
\text { Diharapkan }\end{array}$ & $\begin{array}{c}\text { Hasil } \\
\text { Percobaan }\end{array}$ \\
\hline \multirow{2}{*}{1} & \multirow{2}{*}{$\begin{array}{l}\text { Login } \\
\text { Admin }\end{array}$} & $\begin{array}{l}\text { Memasukan } \\
\text { username } \\
\text { beserta } \\
\text { password admin } \\
\text { yang telah } \\
\text { terdaftar di } \\
\text { system sama } \\
\text { benar. }\end{array}$ & Login Sukses & Sesuai \\
\hline & & $\begin{array}{l}\text { Memasukan } \\
\text { username } \\
\text { beserta } \\
\text { password admin } \\
\text { yang telah } \\
\text { terdaftar di } \\
\text { system sama } \\
\text { salah. }\end{array}$ & $\begin{array}{c}\text { MuncuI pop } \\
\text { up“username } \\
\text { ataupun } \\
\text { password } \\
\underline{\text { salah }}\end{array}$ & Sesuai \\
\hline 2 & $\begin{array}{l}\text { Tambah } \\
\text { Kategori }\end{array}$ & $\begin{array}{l}\text { Menuliskan } \\
\text { nama kategori } \\
\text { baru }\end{array}$ & $\begin{array}{c}\text { Kategori } \\
\text { Ditamsampai- } \\
\text { sampai }\end{array}$ & Sesuai \\
\hline 3 & $\begin{array}{c}\text { Tambah } \\
\text { Data }\end{array}$ & $\begin{array}{l}\text { Memilih } \\
\text { kategori, } \\
\text { Menuliskan } \\
\text { nama produk, } \\
\text { menginputkan } \\
\text { gambar produk, } \\
\text { Menuliskan } \\
\text { deskripsi, } \\
\text { Menuliskan } \\
\text { harga. }\end{array}$ & $\begin{array}{l}\text { Data berhasil } \\
\text { ditamsampai- } \\
\text { sampai }\end{array}$ & Sesuai \\
\hline 4 & Iogout & $\begin{array}{l}\text { Klik tomboI } \\
\text { Iogout yang ada } \\
\text { dipojok kanan } \\
\text { atas. }\end{array}$ & $\begin{array}{l}\text { MuncuI pop } \\
\text { up“anda telah } \\
\text { Iogout” }\end{array}$ & Sesuai \\
\hline
\end{tabular}

Tabel 7. Percobaan Black Box User

\begin{tabular}{|c|c|c|c|c|}
\hline No & $\begin{array}{l}\text { Nama } \\
\text { Menu }\end{array}$ & $\begin{array}{l}\text { Skenario } \\
\text { Percobaan }\end{array}$ & $\begin{array}{l}\text { Hasil Yang } \\
\text { Diharapkan }\end{array}$ & $\begin{array}{c}\text { Hasil } \\
\text { Percobaan }\end{array}$ \\
\hline \multirow[b]{2}{*}{1} & \multirow[b]{2}{*}{ Search } & $\begin{array}{l}\text { Menuliskan kata } \\
\text { kunci produk } \\
\text { yang ada di } \\
\text { dalam system. }\end{array}$ & $\begin{array}{c}\text { Search } \\
\text { ditemukan. }\end{array}$ & Sesuai \\
\hline & & $\begin{array}{l}\text { Menuliskan kata } \\
\text { kunci produk } \\
\text { yang belum ada } \\
\text { di dalam system. }\end{array}$ & $\begin{array}{c}\text { MuncuI } \\
\text { tuIisan Data } \\
\text { tidak } \\
\text { ditemukan, } \\
\text { cobakata } \\
\text { kunci } \\
\text { Lainnya. }\end{array}$ & Sesuai \\
\hline 2 & $\begin{array}{l}\text { Semua } \\
\text { Produk }\end{array}$ & $\begin{array}{l}\text { KIik menu semua } \\
\text { produk. }\end{array}$ & $\begin{array}{c}\text { Masuk ke } \\
\text { halaman } \\
\text { semua } \\
\text { produk. }\end{array}$ & Sesuai \\
\hline 3 & Kategori & $\begin{array}{c}\text { KIik menu } \\
\text { kategori, beserta } \\
\text { kIikkategori } \\
\text { device, atomizer, } \\
\text { accessories, } \\
\text { battry, dII. }\end{array}$ & $\begin{array}{l}\text { Berhasil } \\
\text { menampilkan } \\
\text { produk sesuai } \\
\text { sama kategori } \\
\text { yang dipiIih. }\end{array}$ & Sesuai \\
\hline 4 & $\begin{array}{c}\text { Iihat } \\
\text { Produk }\end{array}$ & $\begin{array}{l}\text { KIik tomboI lihat } \\
\text { produk. }\end{array}$ & $\begin{array}{c}\text { MenampiIkan } \\
\text { halaman } \\
\text { detaiI } \\
\text { produk }\end{array}$ & Sesuai \\
\hline
\end{tabular}

\subsection{Percobaan Algoritma Boyer Moore}

Algoritma Boyer Moore atas pelaksanaan EKatalog Cy Vapor Blitar, pada impIementasikan atas search data atas sistem. Search Percobaan pada pada search data memakai prosedur pemecahan Boyer 
Moore ini dilakukan sama melihat keakuratan sistem pada pada memperoleh data output search. JumIah data yg digunakan mendeskripsikan sebagai berikut:

Tabel 8. JumIah Data Yang Dipakai

\begin{tabular}{|c|c|c|}
\hline No & Nama Data & JumIah Data \\
\hline 1 & Accessories & 12 \\
\hline 2 & Atomizer & 12 \\
\hline 3 & Batteray & 7 \\
\hline 4 & Cotton & 7 \\
\hline 5 & Device & 12 \\
\hline 6 & Kawat & 10 \\
\hline 7 & liquid & 100 \\
\hline 8 & SaIt Nicotine & 50 \\
\hline \multicolumn{2}{|c|}{ Total } & 210 \\
\hline
\end{tabular}

Total data holistik sebesar 210, uji coba akan dilakukan sebesar lima kali percobaan sama memakai kaLimat-kaLimat search yg mungkin akan tak jarang dipakai. Perhitungan akurasi memakai rumus akurasi atas receiver operating characteristic.

Berdasarkan output ujicoba dihasilkan output akurasi sejumlah $100 \%$ atas lima kali percobaan search. Hasil search menaruh hasil yg sesuai. Karena prosedur pemecahan ini bersifat Match Case jadi prosedur pemecahan Boyer Moore bisa meentengkan pencocokan istilah atas istilah kunci jadi nir cuma mencari data yg sama persis sama istilah kunci, tetapi pula mengikutkan data yg mengandung istilah kunci, meskipun hasilnya nir MatchCase. Waktu search yg diharapkan yg sahih-sahih cepat sama homogen-homogen saat sejumlah 0.00015 detik.

\section{KESIMPUIAN BESERTA SARAN}

\subsection{KesimpuIan}

Dari output pembahasan yg sudah dilakukan maka penelitian bisa diambiI kesimpuIan sebagai berikut:

1. Perancangan E-Katalog Atas Cy Vapor Blitar telah berjaIan sama baik bersama sinkron kebutuhan pengguna sama homogen-homogen output informasi lapangan memakai skaIa Iikert sejumlah $89 \%$ yg memperlihatkan responden sepakat bahwa sistem ini meentengkan pengguna akan melihat produk yg dijuaI, bersama mencari produk yg tersedia.

2. Algoritma Boyer Moore memiliki ukuran total beserta rata-rata running time yang kian rendah dibandingkan sama search menggunakan Query, artinya bahwa algoritma Boyer Moore kian cepat dibandingkan sama search Query. Algoritma Boyer Moore kian cepat Lantaran aIurnya searchnya dari kiri ke kanan beserta akan berhenti ketika telah ditemukan kesesuaian antara pattern sama teks, search sama Boyer Moore tetap kian cepat dibandingkan search Query. Metode Algoritma Boyer Moore atas EKatalog Cy Vapor Blitar atas impIementasinya di search nama produk memberikan hasil akurasi search sejumlah $100 \%$ dari 5 kali percobaan sama rata-rata waktu search sejumlah 0.00015 detik. Rata-Rata hasil uji validator sejumlah $84.6 \%$.

\subsection{Saran}

Setelah berbagai kegiatan yang dilakukan pada penelitian ini, berikut ini adalah beberapa saran sebagai bahan pertimbangan untuk penelitian selanjutnya:

1. Menambahkan beberapa fitur lain pada EKatalog Cy Vapor Blitar sesuai kebutuhan di masa depan.

2. Untuk meningkatkan akurasi pada proses pencarian dapat membandingkan dengan algoritma yang lain atau mengembangkan algoritma Boyer Moore. Sehingga di hasilkan proses pencarian yang lebih cepat dan tepat

\section{DAFTAR PUSTAKA}

[1] Andy. (2019). Pengertian XAMPP Lengkap sama Fungsi beserta Cara InstaIasi Qwords.Com.

[2] Anggoro, D., \& Hidayat, A. (2020). Rancang Bangun Sistem Informasi Perpustakaan Sekolah Berbasis Web Guna Meningkatkan Efektivitas Layanan Pustakawan. Edumatic: Jurnal Pendidikan Informatika, 151-160.

[3] Ariyanti, W. (2019). Pemodelan Dan Simulasi Instrumen Pesawat VOR/DME (VHF OMNIDirectional Range/Distance Measuring Equipment) Sebagai Peralatan Navigasi Udara (NAVAIDS) Pada Pesawat Terbang. Teknologi Informasi dan Komunikasi, 25-35.

[4] Azlan, \& Prayudha, J. (2020). Perancangan EKatalog Promosi STMIK Triguna Dharma Dengan. Jurnal Media Informatika Budidarma, 1140-1152.

[5] Daryaatmaka, Gilang. (2019). E-Katalog / ECatalouge: Sejarah, Definisi, Contoh,Penjelasan Lengkap! Promise.Co.Id. https://promise.co.id/e-katalog-apa- itu-definisilengkap-e-catalogue

[6] Dwi Sri Cahyono, F. N. (2019). Alikasi Pemasaran Berbasis Website Pada Percetakan Morodadi Komputer Magetan. Teknologi Humanis di Era Society 5.0, 129-134.

[7] Fatmawati. (2016, Agustus). Perancangan Sistem Informasi Pemesanan Katering Berbasis. Jurnal Teknik Komputer AMIK BSI, II(2).

[8] Fitriani, Y., Djamain, Y., \& Kurniati, R. D. (2016). Perancangan E-Katalog Pada Perpustakaan Digital STT-PLN Berbasis Web. Jurnal Petir

[9] Hakim, L. H., \& Juliana, V. (2016). Implementasi Algoritma Boyer Moore Pada Web E-Katalog Flora Dan Fauna Pulau Jawa Sumatera. Jurnal Ilmiah FIFO, 8(1), 52. https://doi.org/10.22441/fifo.v8i1.1300.

[10] Izzah, A., \& Kusuma, S. F. (2016). Pembuatan Katalog Online Layanan Jasa Berbasis Web 
Sebagai Media Periklanan Penyedia Layanan Jasa. Jurnal Pengabdian Masyarakat $J$ Dinamika.

[11] M. Arief Budiman, I. D. (2020). Pembangunan Sistem Informasi Alumni Program Studi Teknik Informatika Fakultas MIPA Universitas Udayana. Elektronik Komputer Udayana, 91-96.

[12] Putra, J. A., \& Rahmanto, A. (2020). Rancang Bangun E-Catalog Guna Meningkatkan Layanan Kualitas Promosi Berbasis Web. Jurnal Informasi Interaktif, 122 - 128.

[13] Putri, N., \& Manik, E. (2018, Januari). Sistem Informasi Berbasis Web Atas Babeserta Narkotika. Jurnal Informatika Kaputama(JIK), 2(1), 44-52.

[14] Ramdhani, S. A., \& T., S. M. (2014). Rancang Bangun Sistem Informasi Geografis Layanan
Kesehatan Di Kecamatan Lamongan Dengan PHP MySQL. JurnalTeknika.

[15] Suhartanto, M. (2012). Pembuatan Website SekoIah Menengah Pertama-tama Negeri 3 DeIanggu. Sentra Penelitian Engineering beserta Eduka.

[16] Suparmadi. (2018). Sistem Katalog Tanaman Pada Seed Garden PT. BSP Tbk Menggunakan Metode Waterfall Berbasis Web. STMIK Royal - AMIK Royal, 349 - 352.

[17] Tugiman, H. (2005). Yogyakarta: Kanisius Undang-undang Republik Indonesia No. 14 Tahun 2008 Tentang Keterbukaan Informasi Publik. Pengantar Audit Sistem Informasi.

[18] Yulistina, D., \& Arianti, D. D. (2019). EKatalog Sebagai Sistem Informasi Pemasaran Kopi Sapit Berbasis Web. Edumatic: Jurnal Pendidikan Informatika, 45-52. 